\title{
A Quality Study of South Central Timor Regional Drinking Water Company
}

\author{
Lidya Silvia Megasari* David B. W. Pandie William Djani \\ Master Degree Program in Administrative Science, Universitas Nusa Cendana, Kupang, \\ East Nusa Tenggara, Indonesia
}

\begin{abstract}
This study aimed to analyze and describe; (1) the service quality of South Central Timor (SCT) regional drinking water company or PDAM SCT. (2) Supporting and inhibiting factors of the service quality of PDAM SCT. The study was descriptive research with a qualitative approach. This research focused on (1) the quality of service, broken down into sub-focus; (i) Tangible Evidence, (ii) Reliability, and (iii) Responsiveness. (2) Supporting and inhibiting factors of the service quality. Data were collected through interview, documentation, and observation. Data analysis techniques used were interactive models from Miles, Huberman and Saldana (2014: 10) with three components: (1) Data condensation; (2) Data display, (3) Conclusions withdrawal and Verification.

The results showed that the quality of PDAM SCT service has to be improved because many services are still far from the suitability of indicators as an adequate service benchmark.
\end{abstract}

DOI: $10.7176 / \mathrm{DCS} / 10-1-05$

Publication date: January $31^{\text {st }} 2020$

\section{BACKGROUND}

The 2017 PDAM SCT performance, assessed based on the guidelines of the Decree of the Minister of Home Affairs Number 47 of 1999, received a score of 55.438 with "ENOUGH" category. Whereas the 2017 health rating, assessed based on The Supporting Agency for Drinking Water Supply System Development indicators, received a score of 2.325 and was classified as "LESS HEALTHY." Compared to 2016, there was a decrease in the health level by 0.210 .

Table. 1

The 2017 Performance Assessment of PDAM SCT

\begin{tabular}{|l|l|l|}
\hline \multicolumn{1}{|c|}{ Performance } & \multicolumn{1}{|c|}{ Score } & \multicolumn{1}{c|}{ Category } \\
\hline \multicolumn{1}{|c|}{1} & \multicolumn{1}{|c|}{2} & \multicolumn{1}{c|}{3} \\
\hline Level of Service & 55.438 & Enough \\
\hline Health level & 2.325 & Unhealthy \\
\hline
\end{tabular}

Source The 2017 Finance and Development Supervision Body or Badan Pengawasan Keuangan dan

Pembangunan (BPKP) report of East Nusa Tenggara Province

Until 2017 , the total population served was 46,186 people or $10.06 \%$ of the total 459,310 people. While the population in the technical area served were 46,186 inhabitants or $21.32 \%$ of the total 216,629 people. The Government of SCT district is targeting an increase in PDAM service coverage by $20.00 \%$ by the end of 2017 . With service coverage of $10.06 \%$ at the end of 2017 , and taking into account the trend of increasing service coverage in the last three years by $0.51 \%$, as well as other aspects such as water sources and transmission and distribution pipelines, it can be concluded that the PDAM is not ready to support the target of $100 \%$ access to national drinking water.

Nowadays, PDAM SCT is not yet fully able to meet certainty regarding quality, quantity, and continuity. Water quality has not met the requirements stipulated in the Regulation of the Minister of Health No. 492/MENKES/PER/IV/2010, regarding Drinking Water Quality Requirements. The PDAM has not carried out internal supervision over the quality of drinking water following the provisions in the Regulation of the Minister of Health Number 736/MENKES/PER/VI/2010, concerning the Procedure for Supervision of Drinking Water Quality. The average usage for household customers is around $15.95 \mathrm{~m}^{3} /$ customer/month, and the average usage of overall customers is around $17.99 \mathrm{~m}^{3} /$ customer/month so that it meets the provisions in the Minister of Home Affairs Regulation No.23 of 2006, that is the need for monthly household usage around $10 \mathrm{~m}^{3}$. The continuity of water distribution by PDAM SCT is around eight hours/day. This still cannot meet the standards stipulated in the Government Regulation No.122 of 2015 regarding the guarantee of drainage for 24 hours/day as in table 2 below. 
Table. 2 Quality, Quantity, and Continuity Standard of PDAM service

\begin{tabular}{|c|c|c|c|}
\hline $\begin{array}{c}\text { Type of } \\
\text { Service }\end{array}$ & Rule of Law & Standard & Reality \\
\hline 1 & 2 & 3 & 4 \\
\hline Quality & $\begin{array}{c}\text { Regulation of the Minister of Health Number } \\
492 / \text { MENKES/PER/IV/2010 concerning } \\
\text { Management of Drinking Water Quality } \\
\text { Monitoring }\end{array}$ & $\begin{array}{c}\text { Internal Supervision of } \\
\text { Drinking Water } \\
\text { Quality }\end{array}$ & Not yet supervised \\
\hline Quantity & $\begin{array}{c}\text { Regulation of the Ministry of Home Affairs } \\
\text { No. 23 of 2006 concerning Technical } \\
\text { Guidelines and Procedures for Regulating } \\
\text { Water Bills in regional water drinking } \\
\text { company }\end{array}$ & $\begin{array}{c}15.95 \\
\mathrm{~m}^{3} / \text { customer/month }\end{array}$ & $\begin{array}{c}\mathrm{m}^{3} / \text { customer/month } \\
\text { Continuity }\end{array}$ \\
\hline Government Regulation Number 122 of 2015 & 24 hours/day & 8 hours/day \\
\hline
\end{tabular}

Source: The 2016 BPKP report of East Nusa Tenggara Province

PDAM SCT has tried to provide the best service to meet the needs for clean water in the City of SoE, but it is still often receiving complaints from customers. PDAM SCT still cannot solve the problem of the difficulty to get clean water suffered from the community.

The results of observation showed that PDAM SCT service is considered unsatisfactory, which can be seen from the results of the recapitulation of complaints from November to December 2017. In just two (2) months, there were many complaints regarding the lack of clean water services: (1) The quality of clean water service is not good enough, indicated by 367 complaints within two months. (2) The water debit flowed to the customer is different even though in the same scale/type of use. (3) Less proactive to respond to the complaints submitted to officers (long follow-up or even not responded to). (4) Tank water service as an alternative when water congestion is not carried out. (5) Not responsive to customer complaints that do not get water for months. (6) The quality of water is sometimes very dirty. (7) Unclear water schedule/turn system

This study aimed to analyze and describe; (1) the service quality of the regional water drinking company of South Central Timor (SCT) or PDAM SCT. (2) Supporting and inhibiting factors of the service quality of PDAM SCT. Besides, the results of this study are theoretically expected to be useful in developing theory, particularly in term of the implementation of PDAM public service policy. Practically, this research is expected to provide information/the real illustration, especially regarding the implementation of public services and the factors that support and hinder service improvement in PDAM SCT.

\section{LITERATURE REVIEW \\ Public Service \\ Definition of Public Service}

Public services can be defined as service providing of the needs of people or communities who have an interest in the organization under the basic rules and procedures that have been determined. As stated earlier, the government essentially plays a role to serve the community. Moreover, it also aims to create conditions that allow the community to develop their abilities and creativity to achieve a common goal (Rasyid, 1998).

Therefore, public bureaucracy is obliged and responsible to provide good and professional services. Public services are the manifestation of the function of the state apparatus as a civil servant and state servant. Also, public services are intended to prosper the community.

According to Moenir (in Tangkilisan 2007: 208), service is the process of fulfilling the needs through other people's activities. There are two types of services needed by humans: physical services that are personal as human and administrative services provided by others as members of organizations, both mass and state organization.

Based on Kurniawan (2005: 4), public services are a service given to the people or communities who have an interest in the organization as the main rules and procedures that have been determined. Furthermore, according to the Ministry of State Apparatus Utilization and Bureaucratic Reform Decree No.63/KEP/M.PAN/7/2003, public services are all activities carried out by public service providers to meet the needs or to implement statutory provisions.

Kotler also defined service as a profitable activity and offered satisfaction even though the results are not tied to a physical product (Kotler in Lukman, 2000: 8). Kotler's definition is clear that service is a collection or unit that carries out profitable activities, and offers satisfaction even though the results are not physically bound to the product.

Based on the definitions from the experts, it can be concluded that service is an activity or sequence of activities between someone with another person or machine, and provides customer satisfaction. 


\section{The Quality of Public Services}

The quality of service is centered on efforts to meet the needs and desires of customers and the accuracy of delivery to balance the expectations of customers or consumers. According to the Great Indonesia Dictionary, the word "quality" contains many meanings, quality means the level of good or bad, degree of (intelligence, skill, etc.), or quality. The concept of service quality can be understood through consumer behavior, which is a behavior played by consumers in finding, buying, using, and evaluating a product or service expected to satisfy their needs. According to Ibrahim (2008: 22), the quality of public services is a dynamic condition related to products, services, people, processes and the environment where the quality assessment is determined at the time of the delivery of public services. According to Kurniawan (2005: 53-54), quality can be defined as the totality of the characteristics of a product (goods and or services) that support the ability to meet the needs. Quality is often interpreted as anything that satisfies the customer or according to requirements or needs.

Based on Zeithaml, Parasuraman, and Berry (in Pasolong 2010: 135), to find out the quality of service felt significantly by consumers, there are indicators of consumer satisfaction measures that lie in the five dimensions of service quality. Parasuraman et al. (in Tangkilisan 2007: 216-217) modified five main dimensions related to service quality; (1) tangible evidence includes physical facilities, personnel appearances, and communication facilities; (2) Reliability is the ability to provide the promised service immediately, accurately, and satisfactorily; (3) Responsiveness is the desire to provide responsive services; (4) Guarantees includes knowledge, abilities, courtesy, and trustworthiness of staff; (5) Empathy includes ease in good communication relationships, personal attention, and understanding of the needs of customers.

Quality is a dynamic condition related to products, services, people, processes, and the environment that meets or exceeds expectations. The word quality itself contains many meanings, some examples of the notion of quality (Tjiptono (1995) are (1) Compliance with requirements; (2) Suitability for use; (3) Continuous improvement; (4) Free of damage/defects; (5) Meeting the needs of customers from the beginning and at any time; (6) Doing things right; (7) Something that can make customers happy.

\section{The Implementation of Public Services}

Public services can be provided by public and private organizations. Public services can be interpreted as all forms of services, both in the form of public goods and public services whose principle are the responsibility and carried out by government agencies at the central, regional, and within the State-Owned Enterprises or Regional-Owned Enterprises, to meet the needs of the community and to implement the provisions of the legislation (Hardiansyah, 2011).

The implement the quality public services, there must be elements of public service that are fulfilled so that these activities can be said to be public service activities, among others (Choliq, 2011); (1) Systems, procedures, and methods. This means that public services must have information systems, procedures, and methods which support the smooth delivery of services. (2) Personnel, especially emphasized on the behavior of the apparatus. The point is that, in public service, the government apparatus, as service personnel, must be professional, disciplined, and open to criticism, suggestions, and advice from customers and the public. (3) Facilities and infrastructure. This means that public services need equipment, workspaces, and public service facilities such as waiting rooms, parking lots, suggestion boxes, restrooms, and others. (4) Society as a customer, in public services, the community as a customer, is very heterogeneous both its education level and behavior.

\section{Paradigm Shift of Public Service}

Shifts or changes in the administration of government from Reinventing Government (Bureaucratic Entrepreneurship), Good Governance, and New Public Management to New Public Service is an identity shift of the modern government to meet the demands of desire and public needs to be cheap, timely, satisfied, and physical and spiritual happiness. One of the important aspects to be regulated in the administration of public services is service standards. The service standard will guarantee equal access of every citizen to get services from the state administrators.

In the new public service model, public services are based on the democratic theory that teaches equality between citizens. The public interest is formulated as the result of an emancipatory and participatory dialogue of various values and aspirations that develop in the community. The public interest is not standardized by the political elite as stipulated in the rules. The bureaucracy that provides public services must be oriented and responsive to the community. The role of government is to negotiate and explore various interests of citizens and various community groups. In this model, the public bureaucracy must not only be accountable to various legal rules, but also to the values that exist in society, the applicable political norms, professional standards, and the interests of citizens. That is a series of ideal public service concepts in the era of democracy.

In a broad outline, these are the main points of debate of experts regarding the comparison between public and private administration. The Old Public Administration (OPA) is a very pure approach because it refers only to public administration standards that have traditionally been developed since the Middle Ages. Meanwhile, the 
New Public Management (NPM) is trying to incorporate private administrative standards into public organizations to produce the same good performance as business organizations. In a New Public Service approach, the community is like the 'middle ground' that not includes the characteristics of public organizations while trying to improve the performance of public administration pragmatically. See the table below for more detail;

Table. 3 Three Perspectives of Public Administration

\begin{tabular}{|c|c|c|c|c|}
\hline No & Element & OPA & NMP & NPS \\
\hline 1 & 2 & 3 & 4 & 5 \\
\hline 1 & Basic Epistemology & Political theory & Economic theory & $\begin{array}{c}\text { Democratic theory, various } \\
\text { approaches }\end{array}$ \\
\hline 2 & $\begin{array}{l}\text { The concept of } \\
\text { public interest }\end{array}$ & $\begin{array}{l}\text { Something that is } \\
\text { translated politically } \\
\text { and listed in the rules }\end{array}$ & $\begin{array}{l}\text { The public interest } \\
\text { represents the } \\
\text { aggregation of individual } \\
\text { interests }\end{array}$ & $\begin{array}{l}\text { The public interest is the } \\
\text { result of a dialogue of } \\
\text { values }\end{array}$ \\
\hline 3 & Who served is & $\begin{array}{c}\text { Clients \& } \\
\text { constituents }\end{array}$ & Customer & Citizen \\
\hline 4 & Government Role & Pedaling & Directing & Serving \\
\hline 5 & $\begin{array}{c}\text { Rationality \& } \\
\text { Human Behavior } \\
\text { Model }\end{array}$ & $\begin{array}{c}\text { Synoptic rationality, } \\
\text { administrative } \\
\text { human }\end{array}$ & $\begin{array}{c}\text { Technical and economic } \\
\text { rationality, "economic } \\
\text { man", self-interested } \\
\text { decision-makers }\end{array}$ & $\begin{array}{c}\text { Strategic or formal } \\
\text { rationality, multiple } \\
\text { rationality tests (political, } \\
\text { economic, and } \\
\text { organizational) } \\
\end{array}$ \\
\hline 6 & Accountability & $\begin{array}{c}\text { According to } \\
\text { administrative } \\
\text { hierarchy }\end{array}$ & $\begin{array}{l}\text { The market's will is the } \\
\text { result of the wishes of } \\
\text { customers }\end{array}$ & $\begin{array}{c}\text { Many dimensions; } \\
\text { accountability, public, } \\
\text { community, political norms, } \\
\text { professionalism, citizen } \\
\text { interests } \\
\end{array}$ \\
\hline 7 & $\begin{array}{l}\text { Administrative } \\
\text { Discretion }\end{array}$ & $\begin{array}{l}\text { Discretion is limited } \\
\text { to administrative } \\
\text { officers }\end{array}$ & $\begin{array}{l}\text { Broad reach to achieve } \\
\text { entrepreneurial goals }\end{array}$ & $\begin{array}{l}\text { Responsible discretion is } \\
\text { necessary and if neede is } \\
\text { forced }\end{array}$ \\
\hline 8 & $\begin{array}{l}\text { Organizational } \\
\text { structure }\end{array}$ & $\begin{array}{l}\text { Bureaucratic } \\
\text { organization, top- } \\
\text { down authority } \\
\end{array}$ & $\begin{array}{c}\text { Decentralized public } \\
\text { organizations }\end{array}$ & $\begin{array}{c}\text { The collaborative structure } \\
\text { between external and } \\
\text { internal leadership }\end{array}$ \\
\hline 9 & $\begin{array}{l}\text { Mechanisms for } \\
\text { achieving policy } \\
\text { objectives }\end{array}$ & $\begin{array}{l}\text { Through programs } \\
\text { directed by } \\
\text { government agencies }\end{array}$ & $\begin{array}{c}\text { Through the } \\
\text { establishment of } \\
\text { incentive mechanisms } \\
\text { and structures }\end{array}$ & $\begin{array}{l}\text { Forming coalitions between } \\
\text { public agencies, non-profit, } \\
\text { and private sector. }\end{array}$ \\
\hline 10 & $\begin{array}{l}\text { Basic motivation for } \\
\text { regional officials } \\
\text { and administrators }\end{array}$ & $\begin{array}{l}\text { Salaries and benefits } \\
\text { accompanied by } \\
\text { protection for civil } \\
\text { servants }\end{array}$ & $\begin{array}{l}\text { Entrepreneurial spirit, } \\
\text { ideological desire to } \\
\text { reduce the size of } \\
\text { government }\end{array}$ & $\begin{array}{l}\text { Services to the community, } \\
\text { the desire to contribute to } \\
\text { the community }\end{array}$ \\
\hline
\end{tabular}

Source: Denhardt and Denhardt, 2003

\section{Regional Water Drinking Company}

Law Number 5 of 1962 states that regional-owned enterprises or Badan Usaha Milik Daerah (BUMD) are companies whose capital/shares are owned by the Regional Government and company's assets are separated from the State's assets. To provide certain services to the community, almost all Regional Governments have BUMDs, but not all of them generate benefit. BUMD is one of the tools in making regulations with several characteristics: owned and controlled by the Regional Government, producing output to be marketed, and established due to the failure of the government's economic regulatory mechanism (Effendy, 2011).

Based on the Minister of Home Affairs Regulation No. 7 of 1998, the regional drinking water company hereinafter abbreviated as PDAM is a regional-owned enterprise engaged in drinking water services. As one of the sources of Local Own-Source Revenue or Pendapatan Asli Daerah (PAD), PDAM is managed based on the company's economic principles while maintaining social functions. There are three types of functions of the PDAM organizational structure: (1) Type A, with the number of customers $<5000$ people; (2) Type B, totalling up to 100,000 customers; (3) Type C, with the number of customers $>100,000$ people.

In this organizational system, the management of the PDAM consists of the Board of Directors and the Supervisory Board whose members are appointed by the Regional Head. To date, the drinking water distribution network managed by the PDAM has only reached $44 \%$ for urban areas and only $3 \%$ for rural areas in Indonesia 
(Media Indonesia, 2008). PDAM is unable to supply drinking water to the majority of people who need it, especially in terms of quality, quantity, and continuity. This is mainly due to inefficiencies, bureaucratic inertia, and lack of investment, including high water losses that occur in PDAM throughout Indonesia.

This inefficiency caused water companies to suffer a loss. This means that they cannot fund investment to improve and expand access to their services. Meanwhile, consumers are not willing to pay more until the services have improved (Environmental Service Program, 2007).

\section{Previous Study}

As a study material, the researchers pay attention to the results of previous studies. Table 4 below shows the results of the previous study;

Table. 4 Previous Study

\begin{tabular}{|c|c|c|c|c|c|}
\hline \multirow{2}{*}{ No } & \multirow{2}{*}{ Researcher } & \multirow{2}{*}{ Title } & \multirow{2}{*}{ Year } & \multicolumn{2}{|c|}{ Difference } \\
\hline & & & & Previous Study & This study \\
\hline 1 & 2 & 3 & 4 & 5 & 6 \\
\hline 1 & Nurul Prasetyani & $\begin{array}{l}\text { Public Services } \\
\text { Performance } \\
\text { Analysis of Demak } \\
\text { regional water } \\
\text { drinking company }\end{array}$ & 2009 & $\begin{array}{l}\text { What differentiates } \\
\text { this research with } \\
\text { ours is this research } \\
\text { measured } \\
\text { community } \\
\text { satisfaction index for } \\
\text { the service of PDAM } \\
\text { Demak }\end{array}$ & $\begin{array}{l}\text { This research used } \\
\text { descriptive qualitative } \\
\text { methods and focused on the } \\
\text { study of public service } \\
\text { quality to improve PDAM } \\
\text { performance. }\end{array}$ \\
\hline 2 & Iwan Setiyanto & $\begin{array}{l}\text { An Analysis of Clean } \\
\text { Water Needs (A Case } \\
\text { Study of Kutoarjo } \\
\text { Water Treatment } \\
\text { Installation) }\end{array}$ & 2017 & $\begin{array}{l}\text { The results of this } \\
\text { study can predict the } \\
\text { number of house } \\
\text { connections, the } \\
\text { amount of water } \\
\text { needed, PDAM } \\
\text { discharge, and } \\
\text { PDAM water loss. }\end{array}$ & $\begin{array}{l}\text { What differentiates this } \\
\text { research with ours is this } \\
\text { study does not examine the } \\
\text { case of water connection } \\
\text { installation but the service } \\
\text { of PDAM employees by } \\
\text { looking at Tangible, } \\
\text { Reliability, Responsivenes, } \\
\text { Assurance, and Empathy } \\
\text { dimensions. }\end{array}$ \\
\hline 3 & $\begin{array}{l}\text { I Kadek Alit } \\
\text { Manuartha }\end{array}$ & $\begin{array}{l}\text { Service Evaluation of } \\
\text { PDAM Tirta } \\
\text { Mangutama In } \\
\text { Increasing } \\
\text { Satisfaction }\end{array}$ & 2016 & $\begin{array}{l}\text { This study observed } \\
\text { the form of customer } \\
\text { satisfaction and } \\
\text { customer complaints } \\
\text { and evaluated } \\
\text { services based on the } \\
\text { level of satisfaction } \\
\text { and complaints. }\end{array}$ & $\begin{array}{l}\text { This study used a qualitative } \\
\text { descriptive method to } \\
\text { analyze PDAM services as } \\
\text { well as supporting and } \\
\text { inhibiting factors that affect } \\
\text { public services at SCT } \\
\text { district. }\end{array}$ \\
\hline 4 & Armansyah & $\begin{array}{lr}\text { Audit } & \text { System of } \\
\text { PDAM } & \text { service } \\
\text { Information } & \\
\text { (SIPL.PDAM) was } \\
\text { conducted using ITIL } \\
\text { version } 3 \text { Domain } \\
\text { Service } & \text { Transition } \\
\text { and } & \text { Service } \\
\text { Operation } & \\
\end{array}$ & 2017 & $\begin{array}{l}\text { This study focused } \\
\text { on Information } \\
\text { Systems Audit on } \\
\text { SIPL-PDAM and its } \\
\text { use in PDAM } \\
\text { services }\end{array}$ & $\begin{array}{l}\text { Conducting research on } \\
\text { PDAM service performance } \\
\text { through public service } \\
\text { indicators. }\end{array}$ \\
\hline 5 & $\begin{array}{c}\text { Marsela Puspa } \\
\text { Mustikaningrum } \\
\text { and } \\
\text { Endang Raino } \\
\text { Wirjono }\end{array}$ & $\begin{array}{l}\text { Segment Profitability } \\
\text { Analysis } \\
\text { At the PDAM TIRTA } \\
\text { JAYA Cilacap }\end{array}$ & 2013 & $\begin{array}{l}\text { Classification of } \\
\text { customer profits: the } \\
\text { highest customer is a } \\
\text { large industry while } \\
\text { the lowest profit is a } \\
\text { low-cost apartment. }\end{array}$ & $\begin{array}{l}\text { Not looking at the } \\
\text { distribution of profits but on } \\
\text { the factors supporting and } \\
\text { inhibiting service. }\end{array}$ \\
\hline
\end{tabular}

\section{METHODOLOGY}

The study was descriptive research with a qualitative approach. This research focused on (1) the quality of service, broken down into sub-focus; (i) Tangible Evidence, (ii) Reliability, and (iii) Responsiveness. (2) Supporting and 
inhibiting factors of the service quality. This research was conducted in PDAM SCT. The determination of the informants was based on a purposive sampling technique with the consideration of those who involved in the delivery and recipients of water services for PDAM SCT. Source of data was primary and secondary data. Data were collected through interview, documentation, and observation. Data analysis techniques used were interactive models from Miles, Huberman and Saldana (2014: 10) with three components: (1) Data condensation; (2) Data display, (3) Conclusions withdrawal and Verification. Data triangulation technique is used to guarantee the collected data is valid.

\section{RESULTS AND DISCUSSION}

PDAM SCT is a regional-owned company that serves the needs for clean water for the community. The company has the duty and function to carry out drinking water supply for the welfare of the community. These duties and functions will help the smooth of the implementation of the local government to prosper the public health. PDAM is a company formed by the government as a water supply unit, operating under the direction of the central government and is responsible to the Regent.

The results of this study will address the formulation of problems relating to service quality seen from three sub-focuses study; (1) tangible evidences (physical facilities, personnel appearances, and communication facilities); (2) Reliability, namely the ability to provide the promised service immediately, accurately, and satisfactorily; (3) responsiveness, the desire to serve responsively. Furthermore, it will also address the problem formulation of supporting and inhibiting factors of the service quality of PDAM SCT

\section{Service Quality of PDAM CST}

\section{Tangible evidence}

Tangible evidence is the capability of PDAM SCT in showing its existence to the community through the capability of the company to provide physical facilities and infrastructure and the condition of the surrounding environment. Appearance and discipline of officers in serving, ease of the process, and access to services and the ability of officers to use devices in service is an indicator in the assessment of this dimension.

\subsection{Officers' Appearance in Serving Customers}

In serving customers, the tidiness and politeness of officers are also very important because every day they interact with customers so that a neat, clean, polite appearance becomes an assessment element for officers. The results showed that the appearance of officers in providing services is considered quite good. This can be seen from the appearance of officers wearing PDAM uniforms in accordance with applicable regulations.

\subsection{Office Convenience}

The convenience of PDAM office is one of the aspects of customer satisfaction. Convenience is a priority and a measure of the assessment of PDAM service. The convenience for customers can be seen from the availability of facilities and infrastructure as well as the physical appearance of the PDAM office. Facilities and infrastructure: 1 Queue Chairs (11 pieces) 2. Speaker (1 package) 3. Suggestion Box (1 piece) 4. Trash Can (none) 5. Television (none) 6. Parking space (available/spacious enough) 7. Toilet/WC (1 room) 8. Computers/Laptops (5 computers and 8 laptops) 9. Printers (8 pieces) 10. Calculators (5 pieces) 11. Stationary (any) 12. Information Boards (1 piece) 13. Tank Car (1 piece in good condition, 3 in heavily damaged condition) 14. Car Truck (2 pieces and heavily damaged) 15. Car Service ( 1 in a good condition, 1 in a heavy damage) 16. Pumps ( 1 good condition, 2 heavily damaged) 17. Genset (3 pieces in good condition) 18. Water treatment plant (1 unit and heavily damaged).

More than that, PDAM SCT has tried to provide the best with all the limited financial capabilities of the company. Service facilities such as a clean and comfortable waiting room so far only use the side part of the terrace. The long bench is made of wood so can be occupied by 8 customers. The damaged of the waiting room's floor, the leaky roof during the rainy season, and the unavailability of trash cans is a real condition that the researchers encountered at PDAM SCT. In the waiting room, there is no television or other entertainment facilities for customers who are queuing at the payment counter. Customers who want to fo the toilet can use the toilet commonly used by PDAM employees located inside the office.

The results showed that the comfort of PDAM office still really needs to be improved. It can be achieved by repairing facilities and adding several social facilities or supporting facilities.

\subsection{Officers' Discipline in Serving Customers}

The officers' discipline in serving customers is an important thing to be considered. In serving customers, discipline is a form of commitment from companies engaged in public services. Also, it is an important element for assessing satisfaction.

Based on the document of employee attendance, employee attendance is strongly emphasized 
using a fingerprinting machine, and its proof of attendance is measured monthly through employee attendance records. The record becomes a reference for assessing work discipline for all officers in PDAM SCT. The officers' discipline to serve is stated in the announcement of services posted at the service counter. This announcement lists the time of service to pay water bills.

The results of the observation showed that customers are quite satisfied with the discipline of officers in providing services. The service is carried out according to the schedule that has been made, and all facilities that support existing services can be utilized to achieve on-time and maximal service.

1.4. Ease of Process and Access to Services

One of the characteristics of public service is public accountability, where every citizen has the right to get convenience in the service process and ease in accessing services from public organizations. The ease of getting services is given by the employee before and after receiving the services.

The information board provides information related to the service at each counter. Customers can get service information and notifications stuck on the window of the counter or asked to the officer. Also, information related to changes in water flow schedules, schedule restrictions on drainage (congestion), problems with broken network pipes, and changes in administrative costs are always informed by radiogram through the local government broadcast radio (RSPD) of SCT district.

Moreover, a complaint report book has also been provided. The service complaint can be carried out every working day. For congestion service, an explanation will be given, and efforts will be made to improve the quality of service for customers.

\section{Reliability}

The ability to provide immediate, accurate, and satisfying services is an important aspect of reliability for the company to satisfy customer service. In this case, the company, as a service provider, must be reliable. The officers or employees must be able to show their best performance when serving the customers.

\subsection{The Officers' Accuracy in Serving Customers}

The results of observations showed that PDAM employees are quite reliable by following existing capabilities and capacities. Existing procedures and requirements are also easy to complete, easy to understand, and also straightforward. By using tools or supporting facilities, the officers can serve customer optimally, quickly and precisely. Even for new installations, there are no significant obstacles. If there is a long duration of service, this is related to technical matters, such as the time to add pipe network equipment and so on.

\subsection{Clear Public Services}

The results of the study showed that to provide maximum service, customers did not find difficulties relating to procedures or service standards. Most of the respondents said that there were no significant obstacles in fulfilling the procedures and service standards, only a small portion complained about the length of follow-up for service requests. This is caused by ignorance or impatience of the customer to wait for services for technical matters (stock, manpower, and time).

\subsection{The Officers' Ability to Use Assistive Tools}

As someone who uses company services, a customer expects speed and accuracy of service. The accuracy of the schedule is one of the important elements in the public evaluation of the service performance. The right schedule and duration of service will satisfy the customers. The faster the time to provide services, the more competent and reliable the employees are. The implementation of good service is one of the determinants of service quality. Customers will not only satisfy with the quality of service but also highlight how satisfaction is obtained by considering the way to get it. The usage of assistive devices, such as computers/laptops and loudspeakers can speed up the payments. Besides, technical aids mastery can also simplify and shorten the time to serve.

\section{Responsiveness}

Responsiveness is the ability or readiness of officers to provide the services needed. The employees should help customers who need service, require information, or respond to their complaints quickly and accurately.

\subsection{Responding to Every Customer Who Wants To Get Service}

The results showed that there is no problem on the water bill payment because the employee can serve the customers well. Customer relations sub-division, commonly used as a place to submit complaints, can also receive customers' complain and record it for further action.

However, not all complains can be resolved because it depends on the queue, type of complaints (heavy, moderate or mild damage), the presence of experts or technicians, and the stock of available materials. Water congestion still becomes a major complaint. Responding to that problem, PDAM provides tankers that serve customers need for water but cannot fully solve the problem.

\subsection{A Quick and Appropriate Service by Officers}

The results of the study showed that a quick and precise performance is a work performance or an 
excellent work output. A fast and appropriate service shows the behavior of the employees oriented to their task or work. A good and reliable performance is a manifestation of the good service relations between officers and customers.

Fast and appropriate service is determined by the ability and motivation of the officers who value the customer as an important part of the service efforts they do. After conducting field observations, the researchers conducted an analysis and concluded that there was still a lack of understanding between the PDAM officers and the customers, where PDAM had tried their utmost with all the limitations they had to be able to serve the needs of customers.

Meanwhile, there are still many customer complaints related to inadequate and inappropriate services, especially in handling technical complaints. For this reason, the PDAM needs to improve the quality of its services by increasing the number of personnel/technical officers and the means of infrastructure to support technical performance.

\subsection{A Careful Performance of the Officers}

The results showed that a careful service is the concept of service performed by officers. Careful means that officers can serve well, understand customers, and complete their tasks quickly, accurately, and also without leaving a new job as a result of the previous task.

The results showed there must be at least three main things that need to be considered and implemented in improving the quality of meticulous service: (1) High caring attitude to customers; (2) Serving very well; (3) Satisfying customers with an orientation to existing service standards.

Thus, the success of a service program depends on aligning its abilities, attitudes, appearance, attention, actions, and responsibilities.

\subsection{All Complaints Responded By Officers}

One indicator of the assessment of the Reliability dimension is the attitude of the employee as a response in handling complaints from customers. The results of the study of customers as recipients of services and also officers showed that in their daily services, customer relationship sub-division has worked as much as possible, received, recorded, and given an explanation to complaints submitted or certain complaints that need to be followed up.

\section{Supporting Factors of PDAM CST Service}

PDAM CST service certainly cannot be separated from potential supporting factors in sustaining the service function. Supporting factors are the potential things owned by the company so that they can serve customers well. There are several supporting factors possessed by PDAM SCT:

\section{Awareness}

The awareness factor possessed by each apparatus as a public servant can bring someone to a sincere and earnest feeling as a soul's calling in performing their duties and responsibilities. The sense of sincerity expects the employees to work with discipline and optimally as well as serve without discriminating under the respective main tasks.

The results of the study showed that the awareness of PDAM employees is quite high. Generally, employees already understand their respective work and what to do in providing services to customers by following customer needs.

\section{Rule}

In an organization or company, rules are made by management as an authorized party and regulate everything within the organization or company. In other words, the establishment of a company must consider the rules as wheels of service. In providing service, PDAM SCT works under the auspices of the Regional Regulation No.15 of 2011 concerning the Organizational Structure, Work Procedures and Management of CST regional drinking water company and there are company regulations that serve as a benchmark for implementing regulations for employees.

Regional Regulation No. 15 of 2011 concerning the Organizational Structure, Work Procedure and Management of CST regional drinking water company regulates the principal duties and functions of the company, organization and work procedures of each division, income from service and leave services, awards and honors, liability, dismissal, rank, and financial statements.

The results showed that the rule made employees unable to work optimally in providing services to customers. If they violate the rules, they will be given sanctions in accordance with the regulations that apply to the company. Hence, through the enactment of clear and strict rules, the employees must comply with existing service rules and create satisfaction for customers.

\section{Organization}

Standard Operational Procedure (SOP) of the regional drinking water company includes procedures, technical service for installing new water channels, installing new water channels (additional distribution pipes), terminating house channles, reconnecting water channel, customer complaints, and replacement of 
customer water meters.

The results of the study showed that the PDAM has a working mechanism which has been determined by the company. Employees are placed in the fields that have been determined according to their expertise. A good working system and mechanism can be used as a supporting factor for PDAM to provide good services for customers.

\section{Inhibiting Factors of PDAM SCT Service}

PDAM SCT service cannot always take place optimally because it is inseparable from the inhibiting factors that potentially limit the ability of officers in carrying out their service functions. There are several inhibiting factor owned by PDAM SCT:

1. Ability and Skill

An employee with reliable ability and skills can be a good weapon to implement company services because, in addition to other capabilities such as stable finance, sophisticated infrastructure, good management, and strict rules, the most important thing is skilled and qualified human resources.

The results showed that the PDAM SCT still has employees who do not fully have the ability and skills to work, both those who work manually or using technological aids (computers or laptops or other technical tools). Hence, in addition to wanting to learn from oneself, companies also need to conduct training or education for employees to be more proficient in mastering technology to improve their skills and reliability.

2. Service Facility

There are several facilities that become supporting tools: equipment, work equipment, operational vehicles and other supporting facilities that function as main tools/assistants.

The results showed that the service for water bill payment was sufficient, but the social facilities for customers need to be improved. It needs to add other supporting facilities for the sake of customers' convenience. The number of modern working and water treatment facilities and equipment should be added because the company has quite a limited number and only one of the operational vehicles.

3. Income

Revenue is the entire acceptance received by someone as a reward for labor or thoughts or services that have been devoted to another person or agency/organization/company within a certain period. Basically, the income must be able to meet the needs of life for him and the family. The income of employees, which do not meet the needs of life, will more or less affect their willingness to provide services.

The results showed that the current employee income is still not according to the new payroll standard and uses a salary table of ten years ago because so far there has never been a rate increase since the last tariff increase. Explicitly, the obligation to serve can be disrupted because of the need for employees themselves and their families are still limited.

Besides, the results also showed several factors that hinder service: the condition of the pipeline and the source of water reserves (internal factors of the company) and the arrears of payments (external factors of the company). The ability and skills of employees also need to be improved, their number should be increased, the work facilities should be completed, and their welfare must be paid attention. Therefore, there should be special attention and the search for appropriate solutions from PDAM to overcome the things that can hamper its service.

\section{CONCLUSION AND SUGGESTION}

The results showed that the service quality of PDAM TSCT still needs to do a lot of improvement because there were still many service functions which are still far from the suitability of indicators as an adequate service benchmark.

There are several suggestions from the authors to be considered by PDAM SCT : (1) Water distribution equipment that cannot work optimally, caused by old pipes and damaged production facilities, has to be replaced; (2) Trying to meet the availability of raw water that has not been maximized by finding new sources so that the current shortfall in debit can be overcome; (3) Coordinating and cooperating with relevant agencies and asking for help from the NTT PKPAM NTT Work Unit for the rehabilitation of the Bonleu pipeline network.

\section{REFERENCES}

1. Choliq, Abdul. 2011. Pengantar Manajemen. Rafi Sarana Perkasa, Semarang.

2. Denhardt, Janer V, and Denhardt, Robert B. 2003. The New Public Service: Serving Not Steering. M.E.Sharpe, Armonk, N.Y.

3. Effendy, Onong Uchyana. 2011. Ilmu Komunikasi: Teori dan Prakteknya. Remaja Rosdakarya, Bandung.

4. Environmental Service Programe 2007. The Inportant Clean Water

5. Hardiansyah. 2011. Kualitas Pelayanan Publik; Konsep, Dimensi, Indikator, dan Implementasinya. Gava Media, Yogyakarta. 
6. Ibrahim, Amin. 2008. Teori dan Konsep Pelayanan Publik Serta Implementasinya. Mandar Maju, Jakarta.

7. Kurniawan, Agung. 2005. Transformasi Pelayanan Publik. Pembaharuan, Yogyakarta.

8. Laporan Evaluasi Badan Usaha Milik Daerah Kabupaten Timor Tengah Selatan Tahun 2016.

9. Lukman, Dendawijaya. 2008. Manajemen Perbankan. Ghalia Indonesia, Jakarta.

10. Miles, M.B; Huberman, A.M, dan Saldana, J. 2014. Qualitative Data Analysis, A Methods Source book, Edition 3. USA: Sage Publications. Terjemahan Tjetjep Rohindi Rohidi. UI-Press, Jakarta.

11. Pasolong, Harbani. 2010. Teori Administrasi Publik. Alfabeta, Bandung.

12. Rasyid, Ryaas, 1998. Makna Pemerintahan: Tinjauan Dari Segi Etika dan Kepemimpinan. Yarif Watampone, Jakarta.

13. Tangkilisan, Hessel Nogi S, 2007, Manajemen Publik. Grasindo, Jakarta.

14. Tjiptono, Fandy. 1995. Strategi Pemasaran. Andi Offset, Yogyakarta. 